\title{
Rare disease
}

\section{Page kidney in a 17-year-old renal allograft}

\author{
Vanita Gandhi, Maryam Khosravi, Aine Burns \\ Department of Nephrology, Royal Free Hospital, London, UK \\ Correspondence to Dr Vanita Gandhi, vanita.gandhi@doctors.org.uk
}

\section{Summary}

Page kidney is a condition where extrinsic renal compression from a haematoma or mass results in hypertension and loss of renal function. Most cases are caused by a subcapsular haematoma following blunt trauma or invasive procedures (eg, renal biopsy). We report a patient who spontaneously developed Page kidney 17 years after renal transplantation. This case represents the oldest renal allograft to develop non-traumatic Page kidney.

\section{BACKGROUND}

Page kidney is a rare cause of secondary hypertension. There are only around 100 cases described in the literature. The commonest underlying aetiology is haematoma formation following renal biopsy. This case represents the oldest renal allograft to develop spontaneous Page kidney.

\section{CASE PRESENTATION}

A 46-year-old man with a 17 year-old renal allograft presented with right iliac fossa pain and oligouria after cycling 10 miles. The cycle ride had been uneventful and of moderate intensity. Upon dismounting from his bicycle, he felt a dull pain in his abdomen that persisted for 48 hours. His medical history included end-stage renal failure secondary to reflux nephropathy. Physical examination elicited tenderness over the renal allograft but no peritonism.

\section{INVESTIGATIONS}

His blood pressure was $185 / 110 \mathrm{mmHg}$ and serum creatinine was $605 \mu \mathrm{mol} / \mathrm{l}$ (baseline of $170-200 \mu \mathrm{mol} / \mathrm{l}$ ). Ultrasonography revealed a large $3 \times 9 \mathrm{~cm}$ subcapsular haematoma over the entire antihilar cortex of the transplanted kidney (figure 1), with associated elevated resistive indices and absent diastolic blood flow on Doppler. A radiological diagnosis of Page kidney was made.

\section{TREATMENT}

The haematoma was surgically evacuated and the patient had an uneventful postoperative recovery.

\section{OUTCOME AND FOLLOW-UP}

His blood pressure and serum creatinine normalised over the subsequent week. At 3 months follow-up, repeat ultrasonography showed complete resolution of the haematoma and normal appearance of the renal allograft.

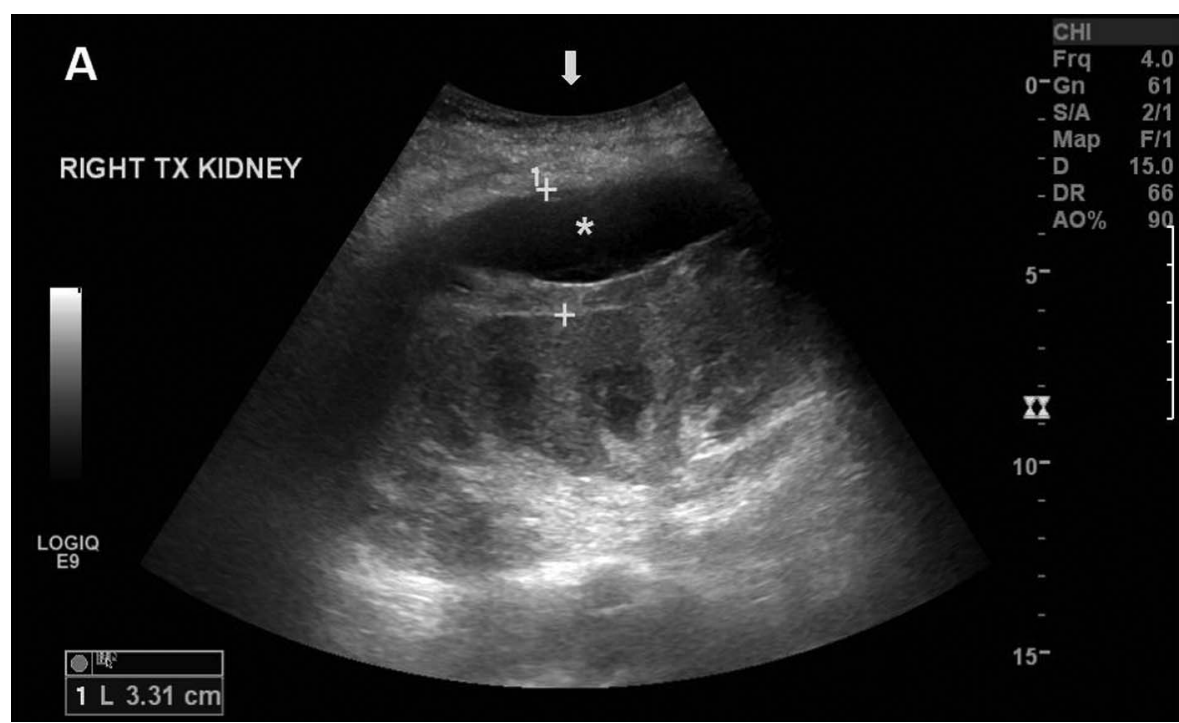

Figure 1 Ultrasonography showing a subcapsular haematoma (asterisk) over the antihilar cortex of the renal allograft. 


\section{BMJ Case Reports}

\section{DISCUSSION}

Page kidney refers to the phenomenon of hypertension with or without acute kidney injury following external renal compression. In 1939, Irwin Page demonstrated this by wrapping canine kidneys in cellophane. ${ }^{1}$ The compression is believed to cause renal hypoperfusion, activation of the renin-angiotensin-aldosterone system, leading to excess salt and water retention and hypertension. ${ }^{2}$

Page kidney occurs in patients of all age groups. The condition has been associated with multiple aetiologies. In the past, the majority of cases were caused by posttraumatic perinephric and subcapsular haematomas. Over the last two decades, Page kidney has increasingly resulted from invasive procedures performed on transplanted kidneys, such as renal biopsies. ${ }^{3}$ Other causes discussed in the literature include renal cysts, lymphoceles and urinomas. $^{4}$

Multiple imaging modalities can be used to aid diagnosis, including ultrasonography, CT and MRI. Standard treatment includes appropriate fluid management and antihypertensive medications, such as ACE inhibitors and angiotensin receptor blockers. Surgical evacuation of a haematoma may be necessary in patients with persistent or refractory hypertension, worsening renal function or large haematomas.

Page kidney is a rare entity with approximately 100 cases described in the literature. One case previously describes spontaneous Page kidney 24 days after renal transplantation. ${ }^{5}$ Our patient has the oldest renal allograft to develop non-traumatic Page kidney.

\section{Learning points}

- Page kidney is a rare but important differential diagnosis to consider in patients with a renal transplant who are presenting with new onset hypertension and pain over their graft.

- Ultrasonography is recommended in all patients with possible Page kidney presenting with renal dysfunction.

- Prompt diagnosis and treatment can prevent irreversible damage to the graft.

\section{Competing interests None.}

Patient consent Obtained.

\section{REFERENCES}

1. Page IH. The production of persistent arterial hypertension by cellophane perinephritis. JAMA 1939;113:2046-8.

2. Engel WJ, Page $\mathbb{H}$. Hypertension due to renal compression resulting from subcapsular hematoma. J Urol 1955;73:735-9.

3. Chung J, Caumartin Y, Warren J, et al. Acute Page kidney following renal allograft biopsy: a complication requiring early recognition and treatment. $\mathrm{Am}$ J Transplant 2008;8:1323-8.

4. Bakri RS, Prime M, Haydar A, et al. Three 'Pages' in a chapter of accidents. Nephrol Dial Transplant 2003;18:1917-19.

5. Butt FK, Seawright AH, Kokko KE, et al. An unusual presentation of a Page kidney 24 days after transplantation: case report. Transplant Proc 2010;42:4291-4

Copyright 2012 BMJ Publishing Group. All rights reserved. For permission to reuse any of this content visit

http://group.bmj.com/group/rights-licensing/permissions.

BMJ Case Report Fellows may re-use this article for personal use and teaching without any further permission.

Please cite this article as follows (you will need to access the article online to obtain the date of publication).

Gandhi V, Khosravi M, Burns A. Page kidney in a 17-year-old renal allograft. BMJ Case Reports 2012;10.1136/bcr-2012-007653, Published XXX

Become a Fellow of BMJ Case Reports today and you can:

- Submit as many cases as you like

- Enjoy fast sympathetic peer review and rapid publication of accepted articles

- Access all the published articles

- Re-use any of the published material for personal use and teaching without further permission

For information on Institutional Fellowships contact consortiasales@bmjgroup.com

Visit casereports.bmj.com for more articles like this and to become a Fellow 